\title{
果肉および種子の成熟過程における遊離糖含有量の変化 \\ Changes of Free Sugar Contents in Sarcocarp and Seed during the Ripening Process
}

かぼちゃ，にがうり，ピーマン，からたちの遊離榶含有量

On the Free Sugar Contents in Pumpkin, Balsam

apple, Sweet pepper and Trifoliata Orange

(昭 和 43 年 2 月 25 日受理)

\author{
松下アヤコ* \\ (Ayako Matsushita)
}

\begin{abstract}
The present investigation was undertaken to see changes of free sugar contents in sarcocarp and seed during the ripening period of pumpkin, balsam apple, sweet pepper and trifoliata orange. Free sugar contents in sarcocarp and seed of various ripening stages were determined by the use of the cutting method of paper chromatograms and micro-BERTRAND method and, more over, the fractional quantitative analysis of these free sugars were studied. During the ripening period of these seeds, glucose and sucrose still continued to exist, while raffinose and stachyose appeared in the later stage of ripening period. The contents of glucose in sarcocarp and seed were in the highest degree of all the sugars throughout the all ripening process. The contents of glucose in sarcocarp of pumpkin, sweet pepper and trifoliata orange gave minimum values at the unripe stage of sarcocarp and gave maximum value at the later stage of ripeness.
\end{abstract}

\section{緒言}

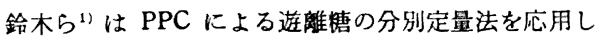
て甘湆の生有中に括ける遊離笤の消長を追跡した。遊離 锘の定量法としてはPPC の応用による楼スポットの分 別, 溶出, Bertrand ${ }^{2)}$ たは Somogyi 法34)による 方法, または PPC の応用による锯スポットの潾度を Densitometer で定量する方法拈よび Glucose oxidase 0) 法によるglucose の定量方法などがみられる。このたび 著者は前報告》) と同粎の方法すなわち paper chromatograms の切りとり, 分割, 溶出および micro-BERTRAND 法早を応用して間接的ではあるか，か沵ちゃ，に がラり，ピーマン，からたちの果肉扰よび種子の成㠇過 程に検出される各遊離綟の分離定量を行ない，試料とし た果肉拉よび種子はそれらの成就の過程中に検出される 遊漼糖の種類とその含有量に变化を生じるとをみとめ たのでこに報告する。

\footnotetext{
* 熊本女子大学家政学部
}

実験

1. 試料

かばちゃ，にがうり，ピーマンを第 1 表の条件で熊本 市の闻場に栽培し, 試料の採集は果肉形成怙よび種子形 成の初期からはじめその後はほほ7日目（からたちは15 〜30日目) 敏に時間を定めて (10〜12時) 成育度の近い ものを採集し，たたちに試験に供した。

\section{2. 試料の調蹩法}

試料の果肉 $200 \mathrm{~g}$ を細断し, 種子 $50 \mathrm{~g}$ は粉末にして用 い,その他は前報》と全く同様の方法によった。

3. 遊離糖の検索

避離棺の検索は前報》) と全く同様の方法によった。な 扣試料中の stachyose(推定), raffinose (推定) のスポ ットの部分加水分解液の paper chromatograms をから たち種子について示せば第 1 図のよ5である。この第 1 困の結果から試料の遊離㗏が標準糖と同じ構成煻である ことがわかり，からたち種子中の stachyose および raffinose を同定し得た。また fructose, glucose, sucro- 
栄着と食粕

第 1 表試 料 の 条件

\begin{tabular}{|c|c|c|c|c|c|c|c|c|c|c|c|c|c|c|c|}
\hline & & （きく涩 & $\varepsilon^{5} 5$ & $\stackrel{+}{\dagger}$ & $k$ & $\overbrace{}^{か ゙}$ & $\begin{array}{ll}5 \\
\text { 小 }\end{array}$ & $\left({ }^{n}\right)$ & $\stackrel{\iota^{\circ}}{(\iota) \bar{r}}$ & 5 疋 & (') & か & 5 & た & $ち$ \\
\hline \multicolumn{2}{|c|}{ 播種時期 } & $\begin{array}{l}3 \text { 月 } \\
25 \text { 日 }\end{array}$ & & & $\begin{array}{l}3 \text { 月 } \\
20 \text { 日 }\end{array}$ & & & & $\begin{array}{r}3 \text { 月 } \\
15 \text { 日 }\end{array}$ & & & & & & \\
\hline \multicolumn{2}{|c|}{ 成熟時期 } & $\begin{array}{l}8 \text { 月 } \\
4 \text { 日 }\end{array}$ & & & $\begin{array}{c}8 \text { 月 } \\
10 \text { 日 }\end{array}$ & & & & $\begin{array}{c}8 \text { 月 } \\
10 \text { 日 }\end{array}$ & & & $\begin{array}{c}9 \text { 月 } \\
15 \text { 日 }\end{array}$ & & & \\
\hline 採 & 集 日 & $\begin{array}{c:c}7 \text { 月 } & \\
14 & 21 \text { 日 }\end{array}$ & 28日 & $\begin{array}{l}8 \text { 月 } \\
4 \text { 日 }\end{array}$ & $\begin{array}{r}7 \text { 月 } \\
19 \text { 日 }\end{array}$ & 26日 & $\begin{array}{l}8 \text { 月 } \\
3 \text { 日 }\end{array}$ & 10日 & $\begin{array}{c}7 \text { 月 } \\
21 \text { 日 } \mid 28 \text { 日 }\end{array}$ & $\begin{array}{l}8 \text { 月 } \\
3 \text { 日 }\end{array}$ & 10日 & $\begin{array}{l}7 \text { 月 } \\
1 \text { 日 }\end{array}$ & 21日 & $\begin{array}{c}8 \text { 月 } \\
15 \text { 日 }\end{array}$ & $\begin{array}{c}9 \text { 月 } \\
15 \text { 日 }\end{array}$ \\
\hline \multirow{2}{*}{$\begin{array}{l}\text { 水 } \\
\text { 分 } \\
\%\end{array}$} & 果 肉 & 88.186 .3 & 85.5 & 83.9 & 96.6 & $|95.1|$ & 94.2 & 93.5 & 97.696 .0 & 94.5 & 92.0 & 94.8 & 93.3 & 92.8 & 91.5 \\
\hline & 種 子 & 68.2 & 51.3 & $40.5^{\prime}$ & & 69.2 & 50.3 & 40.6 & 55.7 & 41.6 & 38.3 & & 60.5 & 59.2 & 58.1 \\
\hline \multirow{2}{*}{ 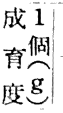 } & 果 肉 & $50.1,212.21$ & 105.32 & 2058.5 & 5.2 & 26.3 & 98.6 & 150.5 & 10.115 .6 & 21.8 & 30.6 & 10. 2 & 25.8 & 51.3 & 70.5 \\
\hline & 種子। & 0.05 & 0.17 & 0.30 & & 0.07 & 0.14 & 0.28 & 0.01 & 0.02 & 0.03 & & $|0.11|$ & 0.25 & 0.32 \\
\hline \multicolumn{5}{|c|}{$\begin{aligned} & \text { Family } \rightarrow \rightarrow \text { Cucurbitaceae } \\
& \text { Genus } \rightarrow \text { Cucurbita } \\
& \text { moschata Duch } \\
& \text { var. } \\
& \text { melonaeformis } \\
& \text { Makino } \\
&\end{aligned}$} & \multicolumn{4}{|c|}{$\begin{array}{l}\text { Cucurbitaceae } \\
\text { Momordica } \\
\text { Charantia L. }\end{array}$} & \multicolumn{3}{|c|}{$\begin{array}{l}\text { Capsicum } \\
\text { annuum L. }\end{array}$} & \multicolumn{4}{|c|}{$\begin{array}{l}\text { Poncirus } \\
\text { trifoliata } \\
\text { Rafin }\end{array}$} \\
\hline
\end{tabular}

se の同定方法も前報》と同栏である。

第1图 Sta, Raf, スポットの东解液の（部分的） paper chromatograms（からたち種子より）

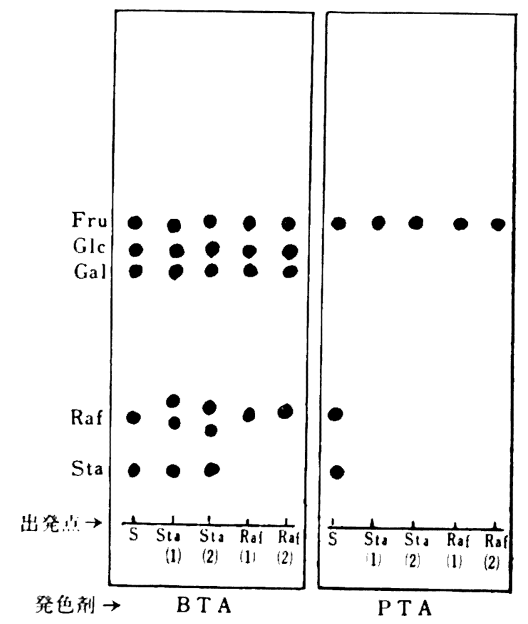

S: 標準燐

Sta: Stachyose の部分水解夜

Sta: Stachyose (陚料の水解液 (部分))

(2)

Raf: Raffinose の部分水解液

Raf: Raffinose (試料の部分水解夜)

BTA $\rightarrow$ Benzidine-trichloroacetic acid

PTA $\rightarrow$ Phloroglucinol-trichloroacetic acid

\section{4. 実験結果および考察}

実䮖結果を第 2 第 5 図拈よび第 2 第 3 表に示す。 第 2 〜第 5 図は果肉扣よび種子の成熟過程に找ける遊離 (186)
糖含有量の paper chromatogram を，かぼちゃとから たちについて示したものである。近来 glucose の定量法 として Glucose oxidase 法尚が使用されているが R. L. Whistlerら ${ }^{(1)}$ は, コーンシラップ中の glucose含量をここ の方法で定量し，その定量値が PPCによる定量値に近 似することを報告の)した。著者の実験值も，なお $\mathrm{Glu}^{-}$ cose oxidase 法による研究が必要であろう。

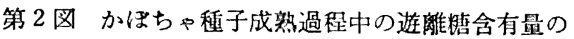 paper chromatograms}

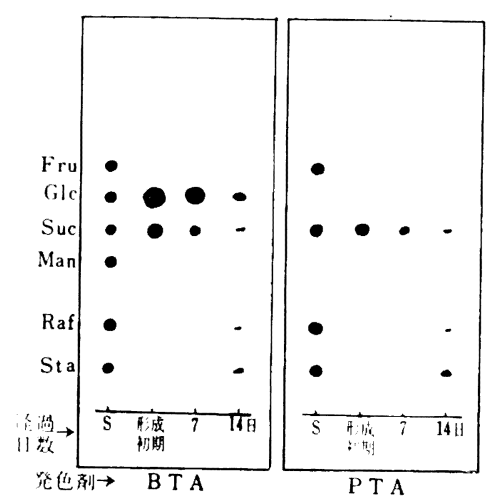

(1) 果肉

1) Sucrose, glucose, fructose につい,

形成初期の陚料の果肉中では glucose が主要な糖 (15.83 4.11\%) であり, その他少量（こんせき〜3.54 \%) の sucrose（かほちゃ，ピーマン，からたち）と, こんせき量の fructose（か涩ちゃ，にが5り）か見出さ 


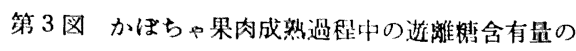
paper chromatograms

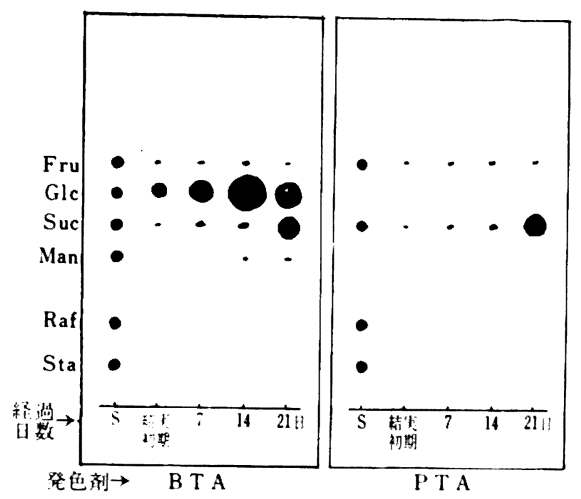

第 4 図からたち種子成就過呈の遊離踏含有量の paper chromatograms

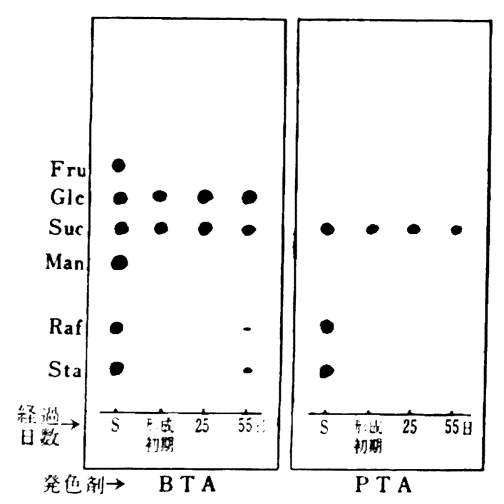

れる。ビーマン，からたち果肉中の sucrose, glucoseの 二種, かぼち果肉中の sucrose, glucose, fructose の 三種,にか; 5 り果肉中の glucose, fructose の二種は果 肉形成の未熟時から成熟にいたる期間中共存する。ピー マン, かぼち, からたち果肉中の glucose は果肉形成 の未熟時に最低量（6.77 15.83\%）を示し, 果肉成就の 後期に一時最高量（17.50～31.99\%）を示すが果肉完熟 期にはやや減量する。にが5り果肉中の glucose は含 量少なく未热時に最高含量 $(4.11 \%)$, 成热期に最低含 量(1.85\%)を示す。ピーマン,からたち果肉中の sucrose 含量は果肉成熟の各過程においてて大差を示さず常に少量 （2.50～5.88\%）である。かぼちゃ果肉中のsucrose含量 は, 果肉形成の未䓡時には, こんせき程度であるが, 果 肉が成欮に近づくと急げきに增量して果肉の完槊期に最
第 5 図からたち果肉成熟過程の遊離狜含有量の paper chromatograms

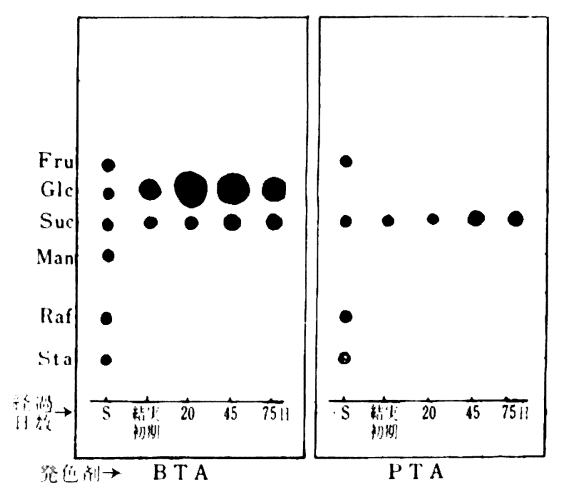

大含量 $(12.23 \%)$ を示す。fructose は，か汇ちゃ，に が5りの果肉成熟の各過程にこんせき程度見出し5る。

2) Maltose について

Maltose はかほちゃ果肉の未熟時には見出しえないが 果実の成然期にこんせき程度見出し5る。

3) 成䓡最後期果肉中の遊離榶

成熟最後期のからたち，かほちゃ果肉中では glucose (12.94〜13.16\%) と sucrose $(5.88 \sim 12.23 \%)$ が主要 な糖であり，かぼちではその他こんせき量の maltose, fructose が見出される。ピーマンでは glucose が主要 な糖 (30.59\%) であり，その他こんせき量の sucrose と fructose のスポットが見出される。にがうり果肉中 の遊離㜍としては少量の glucose とこんせき程度の fructose が見出される。

(2) 種子

1) sucrose, glucose kつい,

形成初期の試料種子中では glucose が主要な糖 (1.79 〜 $8.67 \%$ )でありその他微量〜少量程度のsucrose が見出 される。glucose と sucrose の二種は種子形成初期から 種子の成热にいたる期間中共存する。陚料種子中のglucose とかほちゃ種子中の sucrose は種子の未熟時に最 高量を示し種子の成熟時に最低量を示す。からたち，ピ ーマン,にが5り中の sucrose は成槊の各過程で, 大 した含量の変化がなく常に少量である。

2) Raffinose, stachyose について

Raffinose, stachyoseは未䓡の種子中には見出しえな いが種子の成熟期に出現する。

3）成熟期種子中の遊離塘

成熟した武料種子中の避離榶含有量は果肉の場合に 比して著しく少なく，少量の glucose $(0.47 \sim 1.74 \%)$ sucrose $(0.72 \sim 1.67 \%)$ と微量の stachyose と raffi- 
nose が見出される。

\section{要約}

か㥸らゃ，にがうり，からたち、ピーマンの果肉拈よ び種子の成就過程中の遊崔相含有量の变化状況を paper chromatograms の分制, 溶出および micro-BERTRAND 法を応用して定量を行なった。sucrose，glucoseの 二種は果肉扰よび種子の未就時から成就にいたるまでの

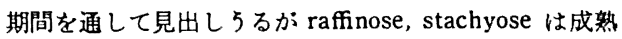
した種子中にのみ見出し 5 る。試料果肉战よび種子中の glucose 含量は未就時から成就時まで常に他の遊離梠の 最高位含量を示し主要な煻である。成就過䅅に㧍ける果 肉中の glucose 含量は概して未熟時に最低量を示し成熟 時近くに最高量を示す。また種子中の glucose 含量は末 努時に最高量を示し成䓡時に最低量を示す。
文献

1）鈴木繁男, 田村太郎, 広幡接夫, 根本芳郎, 荒井克 咗：日㤟化街，31，768（1957）

2）水野卓，金兵忠排：日晨化誌，29，854（1955）

3）渡㲽敏幸, 元村佳恵, 麻生清 : 日费化志, 35, 1038 (1961)

4）上野喬宏：日提化䓌，34，1039（1960）

5）川村偪一郎, 多田稔, 梄崎丁市: 栄養と食䊓, 19, 268 (1966)

6) Whistler, R. L., Hough, L. \& Hylin, J. W.: Anal Chem., 25, 1215 (1953)

7）松下アヤコ：日是化誌，41，646 (1967)

8）逸見文婎，友枝幹夫：日榓化誌，19，386（1943）

\section{䍃卵脂兵の眝藏による变化}

鬼卵を $12.8^{\circ} \mathrm{C} て 228 〜 40$ 日間詝藏したところ, 重量 減, 水分の卵白から卵黄への移動，ハウニニット（鷄卵 重量と卵白の高さの関係を表わし，品質判定の 1 指標)の 減少がみられ。しかし, 全脂質, 各脂質, 全脂肪酸量 および脂質画分の脂肪酸組成はほとんど変化しなかっ た。非りン脂質, フォスファチジルエタノールアミン， フォスファチジルセリン,フォスファチジルコリン，ス フィンゴミェリンの脂肪酸組成を分析し, その特性と相
違点を調べた。眝蔵卵には，脂質の酸化によるるのと推 定される詝藏臭がついたか，現在の分析技術では確実な データは把握できなかった。

Lipid Changes in Shell Egg Composition during Storage.

by Marion, J. E., Woodroof, J. G.: Food Tech., 22. 333 335 (1968)

(钢持) 